\title{
Cell cycle dependent regulation of gap junction coupling and apoptosis in GFSHR-17 granulosa cells
}

\author{
Sabrina Schlie ${ }^{1,2}$, Karolina Mazur ${ }^{1}$, Willem Bintig ${ }^{1}$, Anaclet Ngezahayo ${ }^{1}$ \\ ${ }^{1}$ Institute of Biophysics, University Hannover, Herrenhäuserstr, Hannover, Germany; \\ ${ }^{2}$ Laser Zentrum Hannover e.V., Hollerithallee, Hannover, Germany. \\ Email: ngezahayo@biophysik.uni-hannover.de
}

Received 26 November 2009; revised 10 March 2010; accepted 12 March 2010.

\begin{abstract}
Recent results have shown that the level of gap junction coupling could modulate the induction of apoptotic reactions. We previously observed that $1 \mathrm{H}-[1,2$, 4]Oxadiazole[4,3-a]quinoxalin-1-one (ODQ), a blocker of guanylyl cyclase, inhibited gap junction coupling and thereby promoted activation of characteristic apoptotic reactions such as chromatin condensation, DNA strand breaking, and formation of blebs in GFSHR-17 granulosa cells, the in vitro model for granulosa cells of the maturing ovular follicle. In the present report, we focus on the effects of ODQ with respect to the cell cycle in GFSHR-17 granulosa cells. In synchronised GFSHR-17 granulosa cells, the double whole-cell patch-clamp technique revealed that gap junction conductance in mitotic cells was reduced in comparison to cells in interphase. This reduction of gap junction conductance correlated with a reduction of non-phosphorylated Cx43 in mitotic cells. We compared the stimulation of apoptotic reactions by ODQ between cells in mitosis and in interphase. We observed that the induction of both chromatin condensation and DNA strand breaking by ODQ was increased in mitotic cells, as compared to cells in interphase. The effects of ODQ were not observed in HeLa cells that do not express connexins. The results indicate that reduction of gap junction coupling in mitotic GFSHR-17 granulosa cells depends on phosphorrylation of $\mathrm{Cx} 43$ and raises the sensitivity to stimulation of apoptosis. We propose that gap junction coupling is involved in regulation of apoptosis of granulosa cells in maturing ovular follicle.
\end{abstract}

Keywords: Granulosa Cells; Cell Cycle; Gap Junction; Apoptosis

\section{INTRODUCTION}

Gap junctions are adhesion structures containing cell- to-cell channels that enable neighbouring cells to exchange small molecules $(\leq 1 \mathrm{kDa})$ like $\mathrm{Ca}^{2+}, \mathrm{cAMP}, \mathrm{IP}_{3}$, and to synchronise electrical as well as physiological activities [1,2]. Gap junction channels are composed of connexins (Cx), which are the products of 19 and 20 genes in mouse and human, respectively. The expression and posttranslational modification of the connexins are specifically regulated in the different tissues and correlate with cellular metabolic state [3].

Gap junction assembly involves oligomerisation of six connexins in order to form a connexon that is inserted into the cellular membrane. Two connexons of adjacent cells associate and form a cell-to-cell channel. Since gap junction channels allow a direct intercellular exchange of metabolites and second messengers, specific roles in diseases and regulation of cellular activities including proliferation, transformation, differentiation and apoptosis have been hypothesised $[2,4]$.

Gap junction coupling-dependent regulation of DNA synthesis was shown in cardiomyocytes [5]. It was also observed that gap junction coupling was involved in regulation of expression of cyclin dependent kinase inhibitors (CDK-inhibitors) such as $\mathrm{p} 21^{\text {wafl//ip1 }}$ and $\mathrm{p} 27^{\mathrm{kip} 1}$ in myoblasts [6-9]. Since such CDK-inhibitors block the cell cycle and are invovled in stimulating apoptosis, the previous findings established a link between gap junction coupling and regulation of cell cycle and apoptosis as it was recently proposed [10]. Similarly, a PKC-dependent phosphorylation of $\mathrm{Cx} 43$ that correlates with a reduction of gap junction coupling was found during G2/M phase of the cell cycle [11]

GFSHR-17 granulosa cells, the in vitro model for granulosa cells of the maturing ovular follicle, are a suitable cell system for the analysis of gap junction coupling and apoptosis [12]. They form gap junction channels mainly formed by $\mathrm{Cx} 43$ and $\mathrm{Cx} 45$ [13], which regulate follicular development and atresia [14-16]. Moreover, granulosa cells in the ovular follicles are eliminated by apoptosis during atresia or the deterioration of the corpus lu- 
teum $[17,18]$. During atresia, excess follicles are removed, and dominant follicles, which undergo maturation, are selected. With the deterioration of corpus luteum, the ovary expels superfluous cells that otherwise represent a risk of tumour formation.

Gap junction coupling is regulated by the expression of connexins and posttranslational modifications such as phosphorylation [19]. Since both expression of connexins and posttranslational modification depend on the metabolic state of the cells, it is postulated that gap junction coupling of GFSHR-17 granulosa cells could be modified during the cell cycle. Furthermore, it was shown that the induction of apoptosis is partly related to the degree of gap junction coupling [10]. If the degree of gap junction coupling's regulation is dependent upon the cell cycle, the induction of apoptosis could also be modulated relative to the cycle phase of the GFSHR-17 granulosa cells. This hypothesis was tested by application $20 \mu \mathrm{M}$ ODQ, a dose that was shown to inhibit gap junction coupling in GFSHR-17 granulosa cells [10]. In synchronised GFSHR-17 granulosa cells, we observed that the macroscopic conductance of gap junctions between cells in mitosis was reduced compared to cells in interphase. Correspondingly, non-phosphorylated $\mathrm{Cx} 43$, the main connexin of granulosa cells [13] seemed to be reduced in mitotic cells compared to cells in interphase. The gap junction uncoupler ODQ induces an increase in chromatin condensation as well as DNA strand breaks in cells in the mitotic phase, compared to cells in interphase. The results indicate an involvement of gap junction coupling in cell cycle-dependent modulation of apoptosis.

\section{METHODS}

\subsection{Chemicals and Cell Culture Media}

If not otherwise specified, the chemicals and the cell culture media were obtained from Sigma-Aldrich (Taufkirchen, Germany).

\subsection{Cell Culture}

Granulosa cells were cultivated as described previously $[10,20]$ using Dulbecco's Modified Eagle Medium (DMEM) supplemented with 5\% foetal calf serum (FCS) and antibiotics. The culture medium was renewed every 2-3 days, and the cells were passaged every 7 days. The doubling time of the cells was evaluated by counting the cell density $12 \mathrm{~h}, 24 \mathrm{~h}, 36 \mathrm{~h}, 48 \mathrm{~h}$ and $72 \mathrm{~h}$ after seeding.

To test the effect of the ODQ on GFSHR-17 granulosa cells, a $20 \mathrm{mM}$ stock solution of ODQ in DMSO was prepared. This solution was added to the cell culture medium to achieve a concentration of $20 \mu \mathrm{M} \mathrm{ODQ}$, and DMSO was added to achieve a working concentration of $0.5 \%$ DMSO. The control experiments were performed in cells cultivated in the presence of $0.5 \%$ DMSO. Gap junction coupling, activation of chromatin condensation and DNA strand break were analysed after $6 \mathrm{~h}$ incubation in the presence of ODQ.

\subsection{Synchronisation of the Cells}

To achieve a synchronisation of the GFSHR-17 granulosa cells, mitotic cells were isolated from a monolayer using the mitotic-shake-off technique [21]. This technique is based on the observation that cells in mitosis do not adhere very well to the surface. The monolayer was washed with PBS. After addition of fresh culture medium, the cells in Petri dish were carefully shaken to release cells in mitotic phase into the culture medium. The culture medium with cells in mitotic phase was collected and preserved at room temperature. Fresh culture medium was added to the monolayer, and the cells were incubated in the cell culture incubator for an additional hour. The shaking procedure was repeated twice. The collected cell suspsension was centrifuged at $800 \mathrm{~g}$ for 15 $\mathrm{min}$. The cells in the pellet were resuspended in cell culture medium and counted using a Rosenthal cell counter device. A quantity of $4 \times 10^{4}$ cells were seeded into $2 \mathrm{ml}$ of culture medium in a culture dish with $35 \mathrm{~mm}$ in $\varnothing$. The proliferation was evaluated $1.5,3,4.5,14.5,16$, $17.5,19,20.5$, and $40 \mathrm{~h}$ after seeding. For a better comparison between experiments, the cell population at each time point was normalised to the seeding population at time $0 \mathrm{~h}$. The results are given as average \pm SEM for $\mathrm{n}=$ 4 experiments.

\subsection{Analysis of Gap Junction Coupling with Lucifer Yellow Transfer}

To analyse the effect of ODQ on gap junction coupling of the GFSHR-17 granulosa cells, the cells were grown on cover slips with $10 \mathrm{~mm} \varnothing$. A cover slip with a monolayer was placed in a superfusion chamber containing $0.5 \mathrm{ml}$ of a bath solution containing (in $\mathrm{mM}$ ): $140 \mathrm{NaCl}$, $10 \mathrm{KCl}, 2 \mathrm{CaCl}_{2}, 1 \mathrm{MgCl}_{2}, 5$ glucose and 10 HEPES. After an adaptation to room temperature for at least 30 min, a whole-cell patch-clamp configuration was established on one cell within the monolayer. Lucifer yellow $(0.5 \%)$ was dissolved in the pipette filling solution that contained (in $\mathrm{mM}$ ): $100 \mathrm{~K}$-gluconate, $40 \mathrm{KCl}, 5 \mathrm{Na}_{2} \mathrm{ATP}$, $2.5 \mathrm{MgCl}_{2}, 0.25 \mathrm{CaCl}_{2}, 1$ BAPTA, 0.2 cGMP, 1 glucose and 10 HEPES. The $\mathrm{pH}$ and osmolarity of both the bath and the pipette filling solution were adjusted to 7.4 and $295 \mathrm{mOsmol} / \mathrm{l}$, respectively. Lucifer yellow was allowed to directly diffuse into the cell under whole-cell configuration and through the gap junction channels in the adjacent cells. Ten minutes after establishment of the whole cell configuration, the gap junction coupled cells were counted using a fluorescence microscope (excitation at $438 \mathrm{~nm}$, emission at $510 \mathrm{~nm}$ ). The results are 
given as average \pm SEM for $\mathrm{n}=6$ experiment for each treatment.

\subsection{Analysis of Gap Junction Coupling Using the Double Whole-Cell Patch-Clamp Technique}

The double whole-cell patch-clamp configuration allows imposition of a voltage difference $\left(\Delta \mathrm{V}_{\mathrm{j}}\right)$ between two cells that are joined by gap junction channels. It is thereby possible to evaluate the conductance of the gap junction channels $\left(\mathrm{G}_{\mathrm{j}}\right)$. The double whole-cell patch-clamp configuration was established on pairs of synchronised GFSHR-17 granulosa cells in different phases of the cell cycle. The pipette filling solution and the extracellular solution are described above. These solutions were previously shown to sustain the macroscopic conductance of the gap junction channels [20].

\subsection{Western Blot}

To isolate proteins, cells were collected from the culture dishes in ice cold phosphate buffered solution (PBS) containing (in $\mathrm{mM}$ ): $137 \mathrm{NaCl}, 2.7 \mathrm{KCl}, 10 \mathrm{Na}_{2} \mathrm{HPO}_{4}, 1,8$ $\mathrm{KH}_{2} \mathrm{PO}_{4}, \mathrm{pH}$ 7.4. After centrifugation at $500 \mathrm{~g}$ at $4^{\circ} \mathrm{C}$ for $5 \mathrm{~min}$, the supernatant was discarded, and the cells were diluted in a lysis buffer containing (in $\mathrm{mM}$ ): $10 \mathrm{NaCl}, 25$ HEPES, 2 EDTA, protease inhibitors (aprotinin and phenylmethylsulphonyl fluoride), $\mathrm{pH}$ 7.5. The subsequent sonication at $4^{\circ} \mathrm{C}$ for $10 \mathrm{~min}$ was followed by a centrifugation step at $15000 \mathrm{~g}$ at $4^{\circ} \mathrm{C}$ for $30 \mathrm{~min}$. The supernatant was again discarded and the pellet was dissolved in 30-50 $\mu 1$ of a solubilisation buffer containing (in $\mathrm{mM}$ ): $200 \mathrm{NaCl}, 50$ HEPES, protease inhibitors, $\mathrm{pH}$ 7.5. Equal volume of a $2 \%$ Chaps solution was added to the solubilisation buffer, and a centrifugation step was performed at $6500 \mathrm{~g}$ at $4^{\circ} \mathrm{C}$ for $10 \mathrm{~min}$. The protein concentration in the supernatant was estimated using the Bradford technique. For each experiment, samples containing 5-10 $\mu \mathrm{g}$ of protein were applied to an SDS polyacrylamide gel and separated by electrophoresis. The separated proteins were transferred to a nitrocellulose membrane using 1.2 $\mathrm{mA} / \mathrm{cm}^{2}$ for $120 \mathrm{~min}$. Staining the nitrocellulose membrane was performed by overnight incubation at $4^{\circ} \mathrm{C}$ with the corresponding primary rabbit-anti-Cx43 antibody (Alomone Labs Ltd., Jerusalem, Israel) diluted to 1:1000. The membrane was washed with TBST $(145 \mathrm{mM} \mathrm{NaCl}$, $20 \mathrm{mM}$ Tris- $\mathrm{HCl}, 0.5 \%$ Tween; $\mathrm{pH} 7.5$ ) and then incubated for 1-2 $\mathrm{h}$ with secondary goat-anti-rabbit IgG antibodies conjugated with alkaline phosphatase and diluted to 1:500. The proteins were visualised by Sigma Fast BCIP/NBT (5-Bromo-4-chloro-3-indolyl phosphate/Nitro blue tetrazolium) followed by a final washing step in $\mathrm{H}_{2} \mathrm{O}$. During all washing steps and the incubation with primary and secondary antibody, $3 \%$ milk was used to neutra- lise the non- specific binding.

\subsection{Analysing Chromatin Condensation}

The chromatin structure was analysed by visualisation of nuclear after staining with DAPI. Cells grown on cover slips were fixed by a 10 min incubation in PBS containing $4 \%$ formaldehyde. The cells were permeabilised by incubation in PBS containing 0.3\% Triton X-100 for 10 min. The chromatin was stained by an incubation in PBS containing $1 \mu \mathrm{M}$ DAPI (Invitrogen, Karlsruhe, Germany) for $10 \mathrm{~min}$. The cells were washed and preserved with PBS for further analysis.

The chromatin structure was observed using an inverted fluorescence microscope (Zeiss, Oberkochen, Germany) equipped with a monochomator polychrome II (Hamamatsu, Herrsching, Germany). The excitation wavelength for DAPI ( $348 \mathrm{~nm}$ ) was produced by a $75 \mathrm{~W}$ XBO xenon lamp. Fluorescence images were acquired using a CCD camera (Hamamatsu, Herrsching, Germany) connected to a computer. The monochromator as well as the camera were controlled by Aquacosmos software (Hamamatsu, Herrsching, Germany). The quantitative evaluation of the results was performed by counting the total number of cells as well as the cells exhibiting chromatin condensation in four different areas of each cover slip. The percentage of cells with condensed chromatin was calculated for each cover slip. The results are given as mean \pm SEM for 20 cover slips, for each treatment. At least 1000 cells per treatment were evaluated.

\subsection{Evaluation of DNA Strand Beaks Using Comet Assay}

Comet assay experiments were performed according to previous description [10]. The cells were trypsinised, collected and centrifuged for $10 \mathrm{~min}$ at $800 \mathrm{~g}$. The pellets were resuspended in PBS to $2 \times 106$ cells $/ \mathrm{ml}$. Later, $50 \mu \mathrm{l}$ of the cell suspension was mixed with $100 \mu \mathrm{l}$ of low melting agarose $(0.6 \%)$. One hundred microlitres of this mixture was applied to agarose-coated glass slides and covered with a cover slip. The slides were incubated for $10 \mathrm{~min}$ at $4^{\circ} \mathrm{C}$ for solidification of the agarose. The cover slip was removed, and an addtional $100 \mu \mathrm{l}$ of agarose was added. After solidification at $4^{\circ} \mathrm{C}$, the slides were incubated for $90 \mathrm{~min}$ in a lysis buffer, containing $2.5 \mathrm{M}$ $\mathrm{NaCl} ; 100 \mathrm{mM}$ Na2EDTA; $10 \mathrm{mM}$ Tris; $1 \%$ lauryl sarcosin; $1 \%$ Triton X-100; 10\% DMSO; pH 10. Subsequently, the cover slips were placed in a horizontal gel electrophoresis chamber, filled with an electrophoresis buffer for the alkaline comet assay (1 mM Na2EDTA; 300 $\mathrm{mM} \mathrm{NaOH} ; \mathrm{pH} \geq 13$ ). After 40 min of adaptation to the buffer, electrophoresis was performed $(25 \mathrm{~V} ; 300 \mathrm{~mA}$; $\left.4^{\circ} \mathrm{C} ; 20 \mathrm{~min}\right)$. For neutralisation, the slides were washed three times with Tris-buffer (400 mM Tris; $\mathrm{pH} 7.5)$ and 
dried at room temperature. Comets were visualised by ethidium bromide staining $(20 \mu \mathrm{g} / \mathrm{ml})$ and examined at 200-fold magnification with a fluorescence microscope (Zeiss, Oberkochen Germany), using a xenon lamp and ethidium bromide filter set (excitation at $\lambda=520 \mathrm{~nm}$ ). The images were recorded with a CCD Camera. For a quantitative analysis of the DNA breaking, the tailmoment is an indication of DNA strand breaking, and it was evaluated using comet scoring software (http://www.autocomet.com/home.php). The results are given as the mean of tailmoment \pm SEM $(n=4)$. At least 1000 cells/ treatment were evaluated.

\section{RESULTS}

To analyse gap junctions during different phases of the cell cycle, granulosa cells were synchronised as described above. We found that mitotic cells harvested by mitotic-shake-off completed mitosis within $3 \mathrm{~h}$ and continued to undergo synchronised division for at least two generations every $16 \mathrm{~h}$ (Figure 1). Gap junction coupling of the mitotic cells was analysed using a double whole cell patch-clamp beginning $2 \mathrm{~h}$ before the division and ending $1 \mathrm{~h}$ after the division. Correspondingly, the gap junction coupling of GFSHR-17 granulosa cells in interphase was studied 4-14 $\mathrm{h}$ after the division. It was found that the macroscopic gap junction conductance $\left(\mathrm{G}_{\mathrm{j}}\right)$ in cells in mitotic phase was significantly reduced compared to the conductance of gap junctions in cells in the interphase (Figure 2(a)). At the molecular level, western blotting revealed two forms of $\mathrm{Cx} 43$ (Figure 2(b)). A

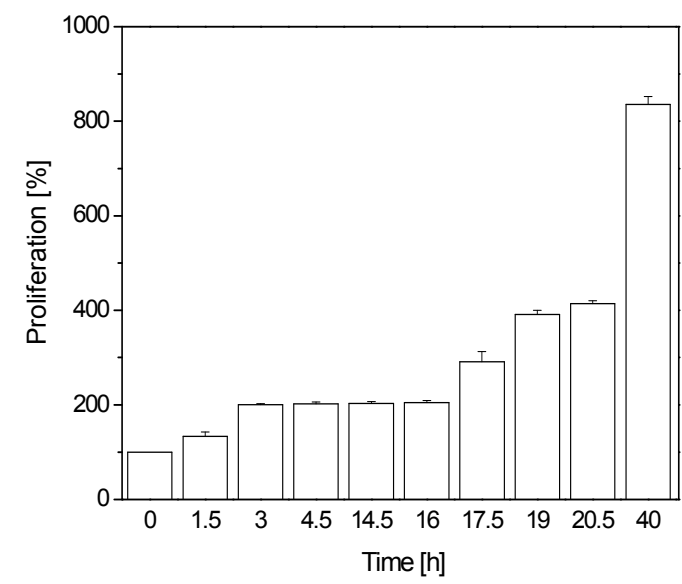

Figure 1. Synchronisation of GFSHR-17 granulosa cells by the mitotis shake off method. It is shown that after selection, the mitotic cells finished mitosis within $3 \mathrm{~h}$. Thereafter, they continued to divide in a synchronous manner for at least two generations. The results were normalised to the population at the seeding time $\left(10^{5}\right.$ cells $)$ and are given as average \pm SEM for at least 10 experiments for each treatment.

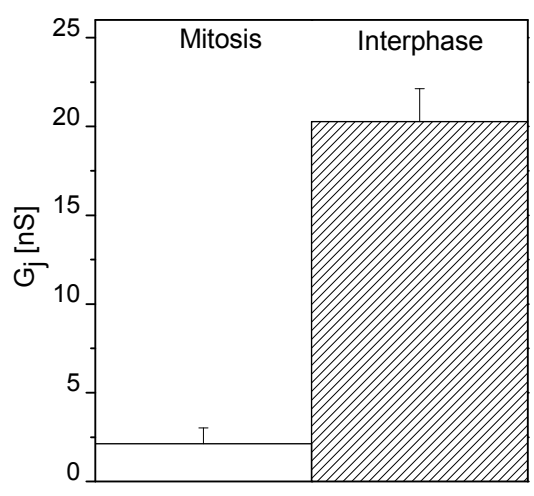

(a)

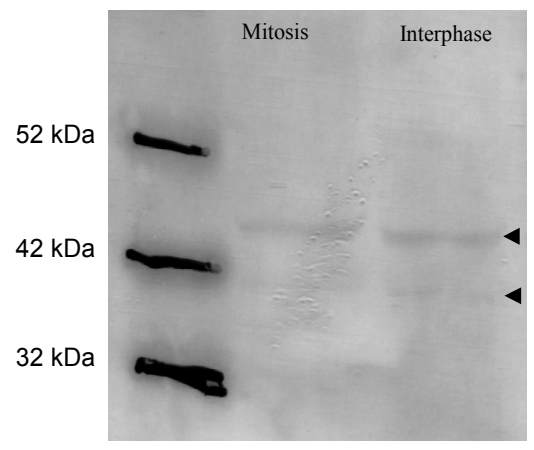

(b)

Figure 2. (a) Absolute amplitudes of the gap junction conductance in cells in interphase, in comparison with cells in mitotic phase. The amplitudes are significantly different ( $\mathrm{p}<0.01$ student's t-test); (b) Western blot analysis showing expression of $\mathrm{Cx} 43$, a representative of three independent experiments. Two bands at 41-42 $\mathrm{kDa}$ and $44-46 \mathrm{kDa}$ can be distinguished in both mitotic cells and in cells in interphase. The bands probably correlate to nonphosphorylated and phosphorylated $\mathrm{Cx} 43$, respectively. It is noteworthy that the nonphosphoprylated ba- nd is more intense in cells in interphase as compared to mitotic cells.

band at $41-42 \mathrm{kDa}$ and a band to $44-46 \mathrm{kDa}$ (Figure 2 (b), arrows). The Western blotting blot result showed in Figure 2(b) is a representative of three independent experiments. For each of these experiments the preparatory work and the blotting of interphase and mitotic cells were performed in parallel. Furthermore special care was taken to use the same quantity of the cells and of protein. Both bands were observed in mitotic cells as well as in cells in interphase. While no difference in intensity of the band at $44-46 \mathrm{kDa}$ was observed, a careful analysis shows a recognisable intensity reduction of the band at 41-42 $\mathrm{kDa}$ for for the mitotic cells compared to cells in interphase (Figure 2(b)). 
Recently, it was shown that inhibition of gap junction coupling correlated with induction of apoptotic processses such as chromatin condensation or DNA strand breaks [10]. Therefore, we hypothesised that the sensitivity to gap junction inhibition-dependent stimulation of the apoptotic process would be increased in mitotic cells, which present low gap junction coupling (Figure 2(a)). After applying the guanylyl cyclase inhibitor ODQ, which has been previously shown to suppress gap junction coupling [10], the following results were obtained. 1) In agreement with our previous results, ODQ inhibits gap junction coupling as shown by dye transfer experiment (Figure 3). Quantitative analysis showed that, 10 min after the establishment of a whole-cell configuration on one cell within a monolayer (Figure 3), Lucifer yellow diffused in only $5.7 \pm 1.5$ ODQ treated cells $(n=6$ experiments), whereas under control conditions, $19.5 \pm$ 4.2 cells ( $n=6$ experiments) were achieved. In interphase cells a dye coupling and an ODQ-related reduction of coupling comparable to that observed in non synchronised cells (Figure 3 ) was found. In mitotic cells the dye coupling was strongly reduced and ODQ treatment could not reinforce the reduction of coupling (results not shown). 2) Analysis of chromatin structure and comet ass-
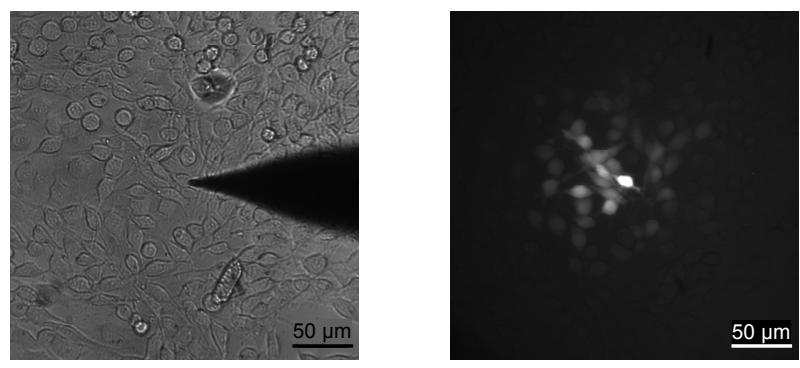

(a)
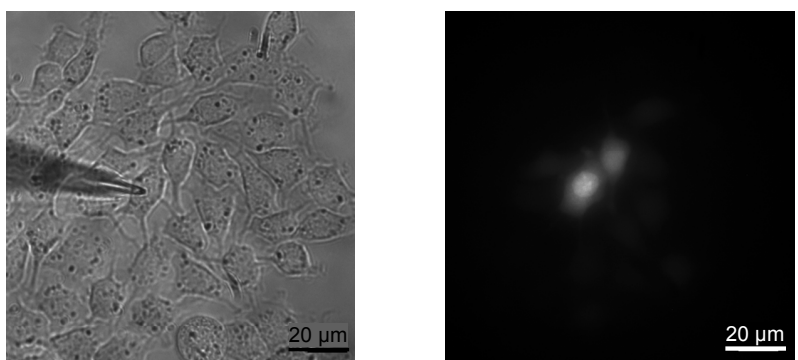

(b)

Figure 3. ODQ reduced gap junction coupling in GFSHR-17 granulosa cells. (a) Control experiment with cells not treated or treated (b) with $20 \mu \mathrm{M}$ ODQ for $6 \mathrm{~h}$. The images were taken 10 min after establishment of the whole-cell patch-clamp configuration on one cell in a monolayer with a pipette filling solution containing $0.5 \%$ Lucifer yellow. Quantitative evaluation showed that, in a monolayer, Lucifer yellow could diffuse into $19.5 \pm 4.2$ cells $(n=6$ experiments) under control conditions, whereas the treatment with ODQ reduced the coupled cells to $5.7 \pm 1.5(\mathrm{n}=6$ experiments $)$. ays respectively revealed that the ODQ-dependent induction of apoptotic reactions such as chromatin condensation or DNA strand breaks was significantly increased in cells in mitotic phase, compared to cells in interphase (Figure 4 and Figure 5). ODQ dependent induction of apoptotic reactions was only observed in cells which normally express gap junction such as GFSHR-17 granulosa cells. Cells which never relay on gap junctions such as HeLa cells were not affected (Figure 4(b) and Figure 5(b)).

\section{DISCUSSION}

The present report shows that gap junction coupling in the GFSHR-17 granulosa cells, the in vitro model for granulosa cell in the maturing ovular follicle [12], is regulated in a cell cycle-dependent manner. We observed that cells in mitotic phase had a reduced gap junction conductance $\left(G_{j}\right)$ compared to cells in interphase (Figure 1, Figure 2(a)). Gap junction communication serves as a pathway for synchronisation of cells in tissues, allowing the formation of physiological units within an organ. However, the cells must be able to evade the community of the cells for individual division. It is therefore hypothesised that mitotic cells reduce their gap junction coupling with neighbouring cells in order to undergo individual division. This hypothesis is in agreement with the observation that cellular division in tissues such as the ovular

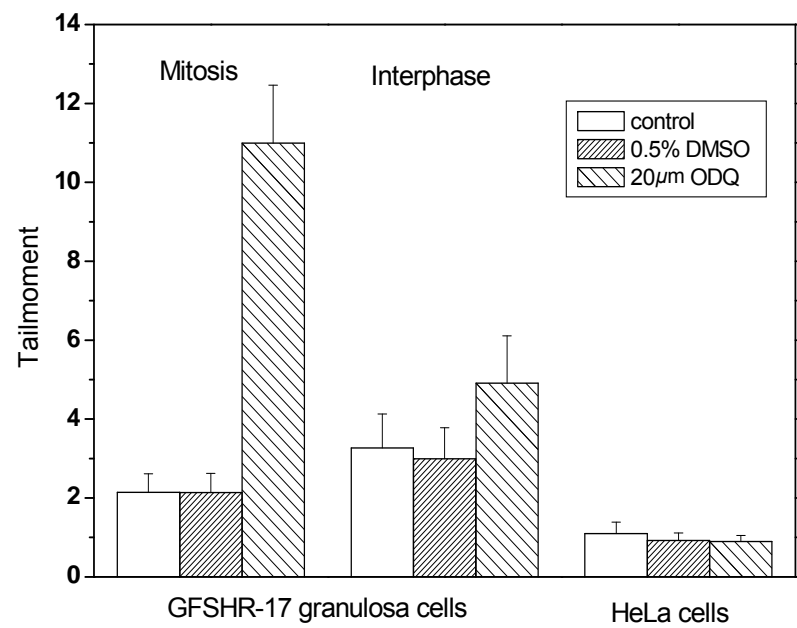

Figure 4. Induction of chromatin condensation by ODQ. (a) The chromatin condensation observed under control conditions (left) and after incubation with ODQ for $6 \mathrm{~h}$ (right). The images are micrographs of cells stained with DAPI and observed under a fluorescence microscope. (b) The portion of cells showing chromatin condensation after treatment with ODQ was significantly ( $\mathrm{p}<0.01$; student's t-test) increased in cells in mitotic phase compared to cells in interphase. The results represent the average \pm SEM for $n=5$ experiments for each treatment. At least 1,000 cells were counted for each treatment. It is noteworthy that $0.5 \%$ DMSO did not affect the chromatin. 

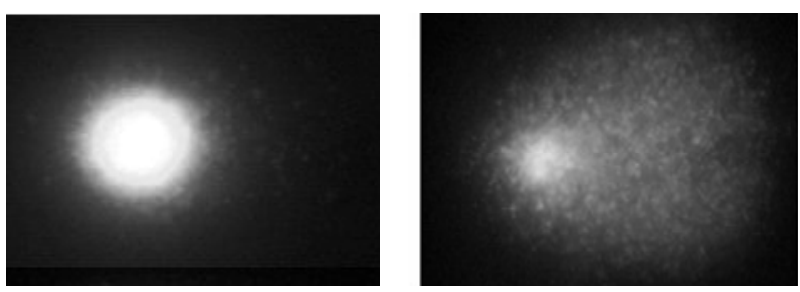

(a)

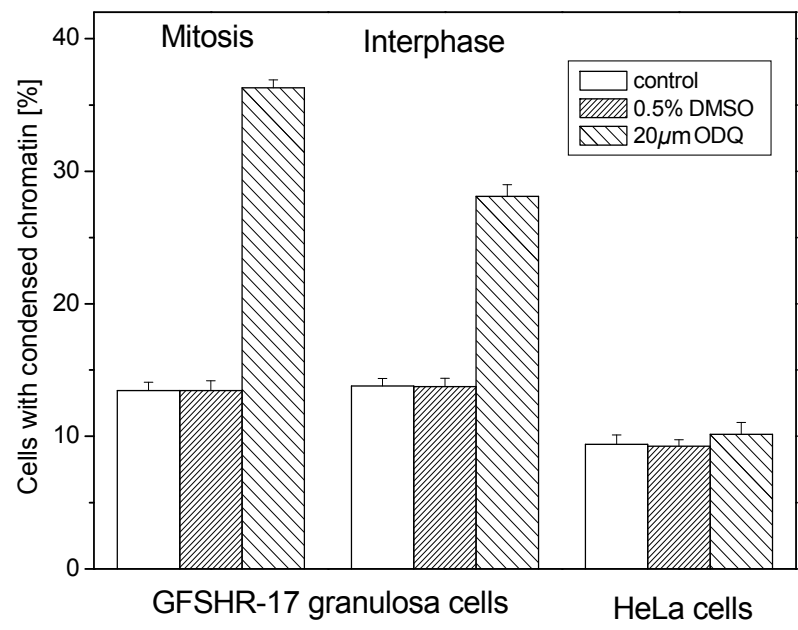

(b)

Figure 5. Induction of DNA strand breaking in GFSHR-17 granulosa cells by ODQ. (a) An example of non-affected cells (left) and affected cells (right) as revealed by comet assay experiments; (b) The tailmoment as a marker of DNA damage induced by treatment with ODQ is increased in cells in mitotic phase than in cells in interphase $(\mathrm{p}<0.01$ student's t-test). The results represent the average \pm SEM for $n=4$ experiments. At least 1,000 cells were counted for each treatment.

follicle is not concomitant [22]. The closure of gap junction stops the exchange of metabolites such as second messengers between the cells [23] and thereby allows individual mitotic division. Two forms of $\mathrm{Cx} 43$ were found in the GFSHR-17 granulosa cells by western blot analysis. These proteins had apparent molecular weights of 41-42 $\mathrm{kDa}$ and 44-46 $\mathrm{kDa}$ (Figure 2(b)). According to Musil et al. [24], the revealed proteins correspond to the non-phosphorylated and phosphorylated forms of $\mathrm{Cx} 43$. A mitosis-dependent reduction of expression of connexins such as $\mathrm{Cx} 43$ was observed in different cell systems such as murine neocortical precursors [25]. However, our western blot analysis does not show a significant reduction of the expression of $\mathrm{Cx} 43$, it only revealed that cells a dislevel of the non-phosphorylated form of $\mathrm{Cx} 43$ compared to cells in interphase (Figure 2(b)). We hypothesise, therefore, that the observed reduction of the conductance of gap junction coupling is related to posttranslational modifications such as phosphorylation. This hypothesis is in agreement with experiments that have shown that phosphorylation reduced gap junction coupling [26] and that the phosphorylation of $\mathrm{Cx}-43$ was increased during the $\mathrm{G} 2 / \mathrm{M}$ phase transition [11].

Recently, we showed that inhibition of gap junction coupling in GFSHR-17 granulasa cells correlated with hallmarks of apoptosis, including induction of chromatin condensation, DNA strand breaks, and formation of blebs [10]. Since we observed that the cells in mitotic phase present a reduced $G_{j}$ compared to cells in interphase and non-synchronised cells (Figure 2(a)), we postulated that the cells in mitotic phase should be more sensitive to the induction of apoptosis by ODQ, which inhibits gap junction coupling [10] (Figure 3). This hypothesis was confirmed by the observation that ODQ induced an increase in the portion of cells with condensed chromatin (Figure 4), as well as an increased tailmoment in cells in mitotic phase, compared to cells in interphase and non-synchronised cells (Figure 5). The importance of the gap junction coupling in the system is also shown by the experiments with HeLa cells which do not express gap junctions. In the HeLa cells which do not relay on gap junctions the ODQ which acts by reducing gap junction did not induce the apoptotic reactions (Figure 4 and Figure 5). Furthermore the results with HeLa cells show that the activation of apoptotic reactions is not a non specific effect of ODQ

Evidence has accumulated that gap junction coupling regulates highly complex cellular functions. It was shown that a reduction of gap junction coupling reduced the differentiation of cultured chick leg bud mesenchymal cells [27], the proliferation and fusion of the myoblast [6, 7] and the differentiation of progenitor cells of the retina $[28,29]$. Additionally, it was observed that inhibition of gap junction coupling was involved in stimulation of apoptosis in granulosa cells $[10,20]$. Diverse molecular mechanisms that could link gap junction coupling to the cellular functions have been described. It was shown that gap junction coupling was involved in regulation of DNA synthesis [5] and in the expression and activation of cyclin-dependent kinase inhibitors (CDK-inhibitors) such as $\mathrm{p} 21^{\text {wafl//ip1 }}$ and $\mathrm{p} 27^{\mathrm{kip} 1}[8,9]$. Furthermore, it is known that expression and activation of $\mathrm{p} 21^{\mathrm{waf} / / \mathrm{Cip} 1}$ and $\mathrm{p} 27^{\mathrm{kip} 1}$ is involved in regulation of the cell cycle and apoptosis in granulosa cells $[17,30]$.

\section{CONCLUSIONS}

Taken together, the observations presented in this report suggest that the non-phosphorylated form of $\mathrm{Cx} 43$ is reduced during the mitotic phase of GFSHR-17 granulosa cells. This yields a reduction of gap junction conductance and could result in elevated activity of the CDK-inhibitors and render mitotic granulosa cells more sensitive to apoptosis compared to cells in interphase. We therefore 
propose that connexins phosphorylation-dependent modulation of gap junction coupling is a relevant mechanism to regulate apoptosis of granulosa cells during the folicular maturation.

\section{ACKNOWLEDGEMENTS}

The authors thank Hans-Georg Hannibal and Frank Koepke for excellent technical support.

The project was partly supported by the project NANOTOME and the DFG project Transregio 37/Q1.

Sabrina Schlie was supported by European Graduate College; Interference and Quantum Applications.

\section{REFERENCES}

[1] Harris, A.L. (2001) Emerging issues of connexin channels: Biophysics fills the gap. Quarterly Review of Biophysics, 34(3), 325-472.

[2] White, T.W. and Paul D.L. (1999) Genetic diseases and gene knockouts reveal diverse connexin functions. Annual Review of Physiology, 61(1), 283-310.

[3] Willecke, K., Eiberger, J., Degen, J., Eckardt, J.D., Romualdi, A., Guldenagel, M., Deutsch, U. and Sohl, G. (2002) Structural and functional diversity of connexin genes in the mouse and human genome. The Journal of Biological Chemistry, 383(5), 725-737.

[4] Nakase, T., Fushiki, S. and Naus, C.C. (2003) Astrocytic gap junctions composed of connexin 43 reduce apoptotic neuronal damage in cerebral ischemia. Stroke, 34(8), 1987-1993.

[5] Doble, B.W., Dang, X., Ping, P., Fandrich, R.R., Nickel, B.E., Jin, Y., Cattini, P.A. and Kardami, E. (2003) Phosphorylation of serine 262 in the gap junction protein connexin-43 regulates DNA synthesis in cell-cell contact forming cardiomyocytes. Journal of Cell Science, 117(3), 507-514

[6] Gorbe, A., Becker, D.L., Dux, L., Stelkovics, E., Krenacs, L., Bagdi, E. and Krenacs, T. (2005) Transient upregulation of connexin43 gap junctions and synchronized cell cycle control precede myoblast fusion in regenerating skeletal muscle in vivo. Histochemistry and Cell Biology, 123(6), 573-583.

[7] Gorbe, A., Krenacs, T., Cook, J E. and Becker, D.L. (2007) Myoblast proliferation and syncytial fusion both depend on connexin43 function in transfected skeletal muscle primary cultures. Experimental Cell Research, 313(6), 1135-1148.

[8] Zhang, Y.W., Morita, I., Ikeda. M., Ma, K.W. and Murota, S. (2001) Connexin43 suppresses proliferation of osteosarcoma U2OS cells through post-transcriptional regulation of p27. Oncogene, 20(31), 4138-4149.

[9] Zhang, Y.W., Chen, X., Wu, D., Liu, W., Wang, J., Feng, Z., Cai, G., Fu, B., Hong, Q. and Du, J. (2006) Downregulation of connexin 43 expression by high glucose induces senescence in glomerular mesangial cells. Journal of the American Society of Nephrology, 17(6), 1532-1542.

[10] Ngezahayo, A., Altmann, B., Steffens, M. and Kolb, H. A. (2005) Gap junction coupling and apoptosis in GFSHR-17 granulosa cells. Journal of Membrane Biology 204, 137-144.
[11] Solan, J.L., Fry, M.D., TenBroek, E.M. and Lampe, P.D. (2003) Connexin43 phosphorylation at S368 is acute during $\mathrm{S}$ and $\mathrm{G} 2 / \mathrm{M}$ and in response to protein kinase $\mathrm{C}$ activation. Journal of Cell Science, 116(pt11), 22032211.

[12] Keren, T.I., Dantes, A., Sprengel, R. and Amsterdam, A. (1993) Establishment of steroidegenic granulosa cell lines expressing follicle stimulating hormone receptors. Molecular and Cellular Endocrinology, 95, R1-R10.

[13] Okuma, A., Kuraoka, A., Iida, H., Inai, T., Wasano, K. and Shibata, Y. (1996) Colocalization of connexin 43 and connexin 45 but absence of connexin 40 in granulosa cell gap junctions of rat ovary. Journal Reprod Fertil, 107(2), 255-264.

[14] Ackert, C.L., Gittens, J.E.I., O’Brien, M.J., Eppig, J.J. and Kidder, G.M. (2001) Intercellular communication via connexin43 gap junctions is required for ovarian foliculogenesis in the mouse. Developmental Biology, 233(2), 248-270.

[15] Wiesen, J.F. and Midgley, R.A. (1994) Expression of connexin43 gap junction messenger ribonucleic acid and protein during follicular atresia. Biology of Reproduction, 50(2), 336-348.

[16] Wright, C.S., Becker, D.L., Lin, J.S., Warner, A.E. and Hardy, K. (2001) Stage-specific and differential expression of gap junctions in the mouse ovary: Connexin-specific roles in follicular regulation. Reproduction, 121, 7788 .

[17] Quirk, M., Cowan, R.G. and Harman, R.M. (2004) Progesterone receptor and the cell cycle modulate apoptosis in granulosa cells. Endocrinol, 145(11), 5033-5043.

[18] Sasson, R. and Amsterdam, A. (2003) Pleiotropic antiapoptotic activity of glucocorticoids in ovarian follicular cells. Biochemical Pharmacology, 66(8), 1393-401.

[19] Lampe, P.D. and Lau, A.F. (2004) The effects of connexin phosphorylation on gap junctional communication. The International Journal of Biochemistry \& Cell Biology, 36(7), 1171-1186.

[20] Ngezahayo, A., Altmann, B. and Kolb, H.A. (2003) Regulation of gap junctional coupling, ion fluxes and cell volume by cGMP in GFSHR-17 granulosa cells. Journal of Membrane Biology, 194(3), 165-176.

[21] Van Rossum, G.S.A.T., Vlug, A.S., van den Bosch, H., Verkleij, A.J. and Boonstra, J. (2001) Cytosolic phospholipase A2 activity during the ongoing cell cycle. Journal of Cellular Physiology, 188, 321-328.

[22] Schumer, S.T. and Cannistra, S.A. (2003) Granulosa cell tumor of the ovary. Journal of Clinical Oncology, 21(6), 1180-1189.

[23] Barker, C.J., Wright, J., Hughes, P.J., Kirk, C.J. and Michel, R.H. (2004) Complex changes in cellular inositol phosphate complement accompany transit through the cell cycle. Biochemical Journal, 380(pt 2), 465-473.

[24] Musil, L.S., Cunningham, B.A., Edelmann, G.M. and Goodenough, D.A. (1990) Differential phosphorylation of the gap junction protein connexin43 in junctional communication-competent and deficient cell lines. The Journal of Cell Biology, 111(5 pt 1), 2077-2088.

[25] Bittman, K.S. and LoTurco, J.J. (1999) Differential regulation of connexin 26 and 43 in murine neocortical precursors. Cerebral cortex, 9(2), 188-195.

[26] Solan, J.L. and Lampe, P.D. (2007) Key connexin43 
phosphorylation events regulate the gap junction life cycle. Journal of Membrane Biology, 217(1-3), 35-41.

[27] Jin, E.J., Lee, S.Y., Jung, J.C., Bang, O.S. and Kang, S.S. (2008) TGF- $\beta 3$ inhibits chondrogenesis of cultured chick leg bud mesenchymal cells via downregulation of connexin 43 and integrin $\beta 4$. Journal of Cellular Physiology, 214, 345-353.

[28] Becker, D.L., Webb, K.F., Thrasivoulou, C., Lin, C.C., Nadershahi, R., Tsakiri, N. and Cook, J.E. (2007) Multiphoton imaging of chick retinal development in relation to gap junctional communication. The Journal of Physiology, 585(pt 3), 711-719

[29] Pearson, R.A., Lüneborg, N.L., Becker, D.L. and Mobbs, P. (2005) Gap junctions modulate interkinetic nuclear movement in retinal progenitor cells. The Journal of Neuroscience, 25(46), 10803-10814.

[30] Andreu-Vieyra, C., Chen, R. and Matzuk, M.M. (2007) Effects of granulosa cell-specific deletion of $R b$ in Inha- $\alpha$ null female mice. Endocrinology, 148(8), 3837-3849. 